\title{
CORRESPONDENCE
}

\section{Alleged thermal erosional structures near Farnham, England}

SIR - For a number of years we have been investigating fluvial activity in regions of contemporary permafrost (High Canadian Arctic and Spitsbergen) and concurrently examining terrace sequences in southern Britain to seek evidence for the former presence of ground ice. Hence the recent paper by Fisher \& Rolls (1982) claiming the identification of thermokarst phenomenon near Farnham is of particular interest especially since we are familiar with the Wrecclesham Pit itself.

A number of points require discussion and we propose to group these as follows:-

\section{Nomenclature}

The term thermokarst has of late become somewhat abused and the paper perpetuates this trend. Washburn (1979) stated 'the term designates topographic depression resulting from the thawing of ground ice' or the American Geological Institute (1962) defined thermokarst as 'settling or caving of the ground due to melting of ground ice'. Admittedly, French (1976) took a more permissive view including the processes of subsidence and collapse with a 'large number of more complex activities'. The latter in fact are essentially covered by the simple process of thermal erosion, an activity which is the crux of the interpretation advocated by Fisher \& Rolls. We would urge the continued distinction between thermokarst sensu stricto associated with collapse or subsidence forms, from thermal erosion by running water. Indeed this separation is evident in their introduction.

\section{Palaeochannels}

It is difficult to comprehend why the authors invoke the intervention of 'periglacial processes', i.e. thermal erosion after the fluviatile event which they accept as the mechanism responsible for the trimming of the Folkestone Sands. We concur with the latter interpretation but cannot see why the trimming and palaeochannel formation are not synchronous events. Indeed we also find it difficult to envisage the cutting of the palaeochannels as an event separate from the deposition of the gravels which fill them.

Our observations at the study site show that sedimentary structures within the gravels persist across the channel fills and this relationship leaves little doubt that the erosion of the Folkestone Sands and emplacement of the lowest gravels was a coeval event. This conclusion eliminates the need to postulate either a high water table or ground ice to permit the formation of the channels since they would have been created in a valley bottom location.

The character of the palaeochannel morphology is admitted by the authors to be the main evidence for involving the presence of ground ice and hence permafrost. We suggest that this interpretation is invalid for the following reasons:

(a) Braided stream channels developed in sands frequently possess morphologies with these forms in both permafrost_and non-permafrost environments including deep scours at channel confluences.

(b) Assuming that there is no vertical exaggeration in the drawn cross-section the palaeochannels were at least $2 \mathrm{~m}$ deep. Annual freezing in the most severe periglacial climates rarely develops ice covers of this magnitude and such thicknesses only occur when there is no snow accumulation. It is probable therefore that unfrozen water would have persisted in the deeper channels and a talik (unfrozen zone) would have become established at the bed. From our observations on a wide range of rivers in the Arctic, permafrost seems only directly to affect river channel morphology where lateral erosion is active.

(c) The authors record an open fabric in the gravels and claim that this is inconsistent with the readily eroded nature of the underlying saturated sand (if unfrozen), particularly in view of the implied high energy flow derived from the presence of coarse gravel. We suggest that the open fabric is a direct product of high energy flow, for such conditions will maintain entrainment of the sand whilst the gravel-sized clasts undergo deposition. The gravel sequences in the quarry commonly reveal 
alternations of open work gravels and sandy (matrix supported) gravels reflecting the fluctuating energy levels of the depositional environment.

(d) The 'unexpected conformity' of channel depth reported by the authors is surely a function of maximum scour within a multi-channel stream system. Such uniformity is a fundamental characteristic of braided channels independent of the climatic environment. Similarly the dense channel network can be ascribed to another basic property of such networks without recourse to pore ice.

(e) Box-shaped forms. The reference to French $(1976, \mathrm{p} .175)$ is inappropriate since he referred to an overall cross-valley profile, with an essentially flat floor flanked by abrupt bounding valley slopes giving an overall shallow box-like form to the valley bottom. Indeed French (caption to fig. 8.4) referred to stream incision in a terrace. No data is presented relevant to the interpretation of the palaeochannels under discussion.

\section{Local evidence for former periglacial environment}

First, we accept that the 'poorly sorted and unstratified debris' which ovcrlies the channel fills is a head (solifluction deposit) but its presence is solely witness to former slope instability and is not diagnostic of permafrost. Indeed a major component of the pioneer case study of solifluction by Andersson (1906) related to the Falkland Islands where permafrost is absent. Clearly the head-gravel unconformity may mask a major hiatus. Secondly, we are perplexed over the relevance of the reference to disturbed gravels described by Dines and Edmunds, for even if the same gravel unit as that infilling the palaeochannel is involved, the fabric modification is obviously epigenetic.

From the foregoing discussion it is clear that in our view no evidence has been presented by Fisher \& Rolls which conclusively supports their case for thermal erosion. Rather the evidence presented is totally consistent with processes associated with a braided river environment but the presence of permafrost is unproven. We urge caution in accepting the periglacial control on valley floors as inferred by recent authors. There is a great danger of slipping into the reinforcement syndrome unless unequivocal evidence for the former presence of permafrost is presented. Usually this latter evidence is lacking and even in areas of present day permafrost the frozen ground has limited influence on the sedimentary structures produced in fluvial systems.

\section{References}

American Geological Institute, 1962. Dictionary of Geological Terms. New York: Dolphin Books. Andersson, J. G. 1906. Solifluction; a component of subaerial denudation. J. Geol. 14, 91-112.

Fisher, P. \& Rolls, J. D. 1982. A thermokarst phenomenon on a terrace of the River Wey, near Farnham, Surrey, England. Geol. Mag. 119, 315-18.

French, H. M. 1976. The periglacial environment. London: Longman.

Washburn, A. L. 1979. Geocryology. London: Arnold.

Department of Geography

P. WORSLEY,

University of Reading

I. D. BRYANT

No. 2 Earley Gate

Whiteknights Road

Reading RG6 $2 \mathrm{AU}$

27th May 1982

Sir - We welcome the interest generated by our interpretation of the Wrecclesham channels. Our replies to what we believe to be the more important of the points raised are broadly arranged in the sequence adopted by Worsley and Bryant.

\section{Palaeochannels}

(i) We separate the main fluviatile event (associated with the planing of the Folkestone Sands) from the incision of the palaeochannels on the ground of contrasting morphology and, by inference, of contrasting process. It is difficult to see how flowing water could plane an extensive surface and at the same time dissect that surface. Consequently, as the channels are incised into the surface they are seen as younger and produced under different circumstances. 